\title{
Effects of Fungicide Treatments for the Control of Epidemic and Exotic Calonectria Diseases in Italy
}

Dalia Aiello, Gabriella Cirvilleri, Giancarlo Polizzi, and Alessandro Vitale, Dipartimento di Gestione dei Sistemi Agroalimentari e Ambientali-sez. Patologia vegetale, University of Catania, 95123 Catania, Italy

\begin{abstract}
Aiello, D., Cirvilleri, G., Polizzi, G., and Vitale, A. 2013. Effects of fungicide treatments for the control of epidemic and exotic Calonectria diseases in Italy. Plant Dis. 97:37-43.

The efficacy of 11 fungicides was evaluated for the control of Calonectria infections on bottlebrush (Callistemon "Masotti") and feijoa (Acca sellowiana), with special emphasis on Calonectria pauciramosa and $C$. morganii, which are the most destructive species in Italian ornamental nurseries. Three nursery experiments were performed with the selected fungicides in order to determine their ability to prevent leaf spot caused by C. morganii on bottlebrush and leaf spot and crown and root rot caused by $C$. pauciramosa on bottlebrush and feijoa. All fungicides were effective in reducing disease infections, except for cyproconazole, propamocarb + fosetyl-Al, and $\mathrm{K}$ phosphite that were the least effective in reducing $C$. morganii leaf spot. In con-

trast, $\mathrm{K}$ phosphite proved more effective in reducing crown and root rot caused by $C$. pauciramosa. Fungicides were also evaluated in growthcabinet experiments for their ability to reduce incidence and severity of leaf spot on bottlebrush caused by the exotic pathogens $C$. pseudomexicana, C. tunisiana, C. polizzii, and C. mexicana. Copper hydroxide, fosetyl-Al, prochloraz, prochloraz + cyproconazole, and tebuconazole were always effective in reducing Calonectria leaf spot on bottlebrush. However, some differences in levels of control might be attributable to Calonectria isolate. Overall, this study clearly indicates that new fungicides can be employed for chemical management of Calonectria infections in ornamental nurseries.
\end{abstract}

Calonectria spp. have been associated with a wide range of disease symptoms on a large number of plant hosts worldwide (9). On horticultural crops, Calonectria spp. have been reported mostly from the Northern Hemisphere, especially in gardens and ornamental nurseries (21). In Italy, mainly two species, Calonectria pauciramosa C.L. Schoch \& Crous and Calonectria morganii Crous, Alfenas \& M.J. Wingf., are widespread in nurseries and cause extensive damage on various ornamental plants. A wide range of disease symptoms has been recorded, including crown and root rot, leaf spots, stem canker, and cutting rot on several species, most commonly belonging to plants in the families Anacardiaceae, Arecaceae, Ericaceae, Fabaceae, Myrtaceae, Polygalaceae, Rhamnaceae, and Sapindaceae (30-33,37-39,43,47). Recent studies have indicated that $C$. pauciramosa included cryptic species belonging to the $C$. scoparia complex, and multigene phylogeny analysis recognized $C$. polizzii sp. nov. L. Lombard, Crous \& M.J. Wingf. in Italy (22). During a more recent survey in Tunisia, additional species such as $C$. pseudomexicana sp. nov. L. Lombard, G. Polizzi \& Crous; C. tunisiana sp. nov. L. Lombard, G. Polizzi \& Crous; and C. mexicana C.L. Schoch \& Crous, were observed to cause disease on young plants of Callistemon spp. and other ornamental species (23).

Chemical control of Calonectria diseases is necessary for reducing damage to young plants in the nursery. Various fungicides and different methods of application have been proposed to control diseases caused by Calonectria spp. $(9,16)$. Only preventative measures were found effective, while no curative effects could be obtained for controlling these diseases (9). The use of fungicides (i.e., benomyl, carbendazim, chlorothalonil, copper compounds, prochloraz, and thiophanate-methyl) is a common method for control of these infections in nurseries $(5-7,11-13,19,25,26)$. However, benzimidazole-resistant strains were reported in Italy and

Corresponding author: A. Vitale, E-mail: alevital@unict.it

Accepted for publication 16 July 2012.

http://dx.doi.org/10.1094/PDIS-03-12-0266-RE

(C) 2013 The American Phytopathological Society
Brazil $(1,35,44)$. In different trials, regular applications of copper compounds provided good control of Calonectria infections $(6,9,30)$ whereas. in other trials, repeated applications were shown to induce phytotoxicity to some seedling species $(6,46)$. In addition, some fungicides such as prochloraz or chlorothalonil show variable control of natural infections occurring in nurseries $(9,30,36,46)$. In Sicily (southern Italy), several fungicide applications are made in the nursery during all young growing stages (i.e., seeding, rooting, and pot transplanting) to control crown and root infections, and a fungicide treatment schedule for controlling leaf infections is necessary from August to December. Despite the application of various chemical treatments, epidemics of Calonectria disease frequently occur in nurseries.

Thus, the aim of this work was the evaluation of new fungicides that might be proposed to control Calonectria diseases in the nursery. This study evaluated fungicides using two approaches: (i) nursery experiments to assess the effectiveness of selected fungicides in controlling $C$. pauciramosa and $C$. morganii infections on bottlebrush and feijoa plants and (ii) growth chamber experiments to assess the efficacy of fungicides against C. polizzii, C. pseudomexicana, C. tunisiana, and C. mexicana on bottlebrush.

\section{Materials and Methods}

Fungal isolates. Six pathogenic isolates belonging to the genus Calonectria - C. morganii (CBS 120930 from Callistemon hybrid 'Rose Opal', Catania, Italy), C. pauciramosa (CBS 130333 from Callistemon citrinus (Curtis) Skeels, Catania, Italy), Calonectria polizzii (CBS 130351 from Myrtus communis, Tunis, Tunisia), C. pseudomexicana (CBS 130354 from Callistemon sp., Tunis, Tunisia), Calonectria tunisiana (CBS 130357 from Callistemon laevis An., Tunis, Tunisia), and Calonectria mexicana (CBS 130353 from Dodonaea viscosa, Tunis, Tunisia)-were used in this study $(9,22,23,32)$. In previous studies, C. pauciramosa CBS 130333 was reported as resistant to benzimidazoles, with minimum inhibitory concentration (MIC) between 10 and $100 \mu \mathrm{g} \mathrm{ml}^{-1}$ (32,35), while C. morganii CBS 120930 was found sensitive to benzimidazoles $(37,44)$. In more recent laboratory assays, the employed isolates of $C$. pseudomexicana, $C$. tunisiana, and $C$. mexicana had an MIC to benzimidazoles between 1 and $10 \mu \mathrm{g} \mathrm{ml}^{-1}$ whereas an $\mathrm{MIC}>100 \mu \mathrm{g} \mathrm{m} l^{-1}$ was found for C. polizzii (G. 
Polizzi, data not published). Fresh cultures of each isolate were obtained by transferring agar plugs from stock cultures onto synthetic low-nutrient agar plates (24). Inoculum was prepared by culturing the fungi on potato dextrose agar (PDA) dishes incubated at $25^{\circ} \mathrm{C}$ for 10 to 14 days. Conidial suspensions were prepared by flooding the dishes with sterile distilled water, gently rubbing the colony surface with a sterile loop, and filtering the suspension through a triple layer of cheesecloth into a flask to collect conidia. Final conidial concentrations were determined using a hemocytometer and adjusted to a final concentration of 1 to $2.5 \times 10^{5}$ conidia $\mathrm{ml}^{-1}$.

Fungicides. Commercial formulations of 11 fungicides representing eight chemical groups (Table 1) were evaluated for their efficacy at the standard use rates in reducing Calonectria leaf spot and crown and root rot on bottlebrush (Callistemon "Masotti") and feijoa (Acca sellowiana Berg.).

Nursery experiments. The fungicides employed in these experiments were selected based on preliminary data obtained according to a reliable red clover method for screening disease control measures, used in a previous study (45). Eleven fungicides were tested in three nursery experiments for ability to control artificial infections caused by $C$. morganii and $C$. pauciramosa on bottlebrush cuttings and feijoa seedlings, respectively. C. morganii was used only for leaf inoculation on bottlebrush, while $C$. pauciramosa was also inoculated on crown and root area of feijoa seedlings. All experiments were conducted on 4-by-4-cm-diameter potted plants grown in a commercial nursery located in Catania province (Sicily, Italy).

In experiments I and II, the fungicide treatments were evaluated for the control of bottlebrush leaf spot caused by $C$. morganii and C. pauciramosa. In experiment III, the efficacy of the fungicides was assessed against crown and root rot on feijoa caused by $C$. pauciramosa. Each treatment was replicated three times with 210 (for C. morganii) and 70 (for C. pauciramosa) bottlebrush cuttings/replicate and 32 feijoa seedlings/replicate. The same number of untreated and inoculated control plots was also included in each experiment. According to common nursery practices, irrigation was provided every 1 to 2 days to young plants for the entire duration of the study with overhead sprinklers placed at $1.5 \mathrm{~m}$ in height.

Fungicide suspensions were prepared according to manufacturers' recommended concentrations, as indicated in Table 1. Fungicide treatments were performed by spraying to run-off using a hand sprayer or by applying approximately $0.5 \mathrm{ml} /$ pot as a drench to the crown of feijoa seedlings a day prior to Calonectria inoculations. Plant inoculations were made by using $1-2.5 \times 10^{5}$ conidia $\mathrm{ml}^{-1}$ suspensions. Bottlebrush cuttings were sprayed to leaf wetness with a hand sprayer, while a soil drench with conidial suspension (about $6.5 \mathrm{ml} / \mathrm{pot}$ ) was applied onto the crown area of feijoa seedlings. No surfactants or wetting agents were added to the fungicide and conidial suspensions. After inoculation, bottlebrush cuttings were maintained for $72 \mathrm{~h}$ under plastic bags. All fungicide treatments consisted of a single application on bottlebrush cuttings whereas they were repeated twice at a 15-day interval on feijoa seedlings.

Fungicides efficacy was evaluated by calculating disease incidence (DI) and symptoms severity (SS) 10 to 20 and 80 to 120 days after Calonectria inoculations on bottlebrush cuttings and feijoa seedlings, respectively, once symptoms were observed in untreated plots. DI was calculated as a percentage resulting from number of plants showing symptoms out of the total number of plants examined $\times 100$. The SS value, calculated based on a percentage of infected foliar surface caused by $C$. morganii or $C$. pauciramosum on bottlebrush cuttings, was collected on a fivepoint scale, as follows: $1=$ healthy seedling and $2=1$ to $5 \%, 3=6$ to $25 \%, 4=26$ to $50 \%, 5=$ more than $50 \%$ of infected surface up to blighting of entire leaf. A single value was obtained using the mean of five leaves per plant. The SS of crown and root rot caused by $C$. pauciramosa was determined on all plants after their extirpation using a 1-to-5 scale on the basis of percent area with crown and root rot, where $1=$ no infection and $2=1$ to $16 \%, 3=17$ to $33 \%, 4=34$ to $50 \%$, and $5=$ more than $50 \%$ of infected crown and root area. SS values were converted to mean disease rating (MDR) that was calculated as $\Sigma$ (the number of disease plants or leaves in this class $\times$ the disease class) number of plants or leaves scored. These experiments were conducted twice.

Growth chamber experiments. Four experiments were carried out in growth chambers to evaluate the effects of eight fungicides (Table 1) in reducing bottlebrush leaf spot caused by C. polizzii (occasionally reported in Italy) and C. pseudomexicana, C. tunisi$a n a$, and $C$. mexicana (exotic fungi; not reported in Italy). Each treatment was replicated three times with 70 bottlebrush cuttings/replicate. Pathogen inoculations and disease rating were done as in the $C$. pauciramosa and $C$. morganii nursery experiments. Fungicides were applied $3 \mathrm{~h}$ before pathogen inoculations by spraying bottlebrush cuttings to run-off. Bottlebrush cuttings were covered with plastic bags and incubated in a growth cabinet (Hitec; Mecter S.A.S.) at $25^{\circ} \mathrm{C}$ under near-UV light with a 16-h light-anddark regimen. Evaluation of fungicide effects was determined 6 to 8 days after inoculations. Each experiment was performed twice.

Statistical analyses. Data from the seven experiments were analyzed separately by using the Statistica package software (version 7; Statsoft Inc.). In all repeated experiments, the arithmetic means of DI and MDR were calculated, averaging the values determined for the single replicates of each treatment. Percentage data concerning DI were transformed into the arcsine $\left(\sin ^{-1}\right.$ square root $x$ ) prior to analysis of variance (ANOVA), whereas SS values were not transformed. Initial analyses of DI were conducted by calculating $F$ and $P$ values associated for all experiments to evaluate

Table 1. Features and rates of fungicides used for nursery and growth chamber experiments

\begin{tabular}{|c|c|c|c|c|c|c|}
\hline Active ingredient & $\begin{array}{l}\text { Group name } \\
\text { (FRAC code) }^{x}\end{array}$ & $\begin{array}{l}\text { Rates (g or ml } \\
\text { per } 100 \text { liters) }\end{array}$ & Trade name & Manufacturer & $\begin{array}{c}\text { Formulation } \\
(\%)^{\mathrm{y}}\end{array}$ & $\begin{array}{c}\text { Fungicide } \\
\text { use }^{z}\end{array}$ \\
\hline Thiophanate-methyl & MBC (1) & 100 & Faro & Gowan Italia & $38.3 \mathrm{SC}$ & All \\
\hline Cu hydroxide & Inorganic (11) & 250 & Ekoram 2000 & Du Pont De Nemours & $35 \mathrm{WG}$ & All \\
\hline Fosetyl-Al & Phosphonate (33) & 300 & Aliette & Bayer CropScience & $80 \mathrm{WG}$ & All \\
\hline Cyproconazole & DMI (3) & 30 & Caddy & Bayer CropScience & $10 \mathrm{WG}$ & I and III \\
\hline Prochloraz + cyproconazole & $\operatorname{DMI}(3,3)$ & 300 & Tiptor Xcell & Syngenta Crop Protection & $16.15+2.15 \mathrm{EC}$ & All \\
\hline Prochloraz & DMI (3) & 100 & Octave & Basf Italia & $46.1 \mathrm{WP}$ & All \\
\hline Tebuconazole & DMI (3) & 60 & Horizon & Bayer CropScience & $25.8 \mathrm{EW}$ & I, II, IV-VII \\
\hline Azoxystrobin & QoI (11) & 100 & Quadris & Syngenta Crop Protection & $22.9 \mathrm{SC}$ & All \\
\hline Trifloxystrobin & QoI (11) & 25 & Flint & Bayer CropScience & $50 \mathrm{WG}$ & All \\
\hline Propamocarb + fosetyl-Al & $\begin{array}{l}\text { Carbamate (28), } \\
\text { phosphonate (33) }\end{array}$ & 300 & PrevicurEnergy & Bayer CropScience & $47.2+27.6 \mathrm{SL}$ & I and III \\
\hline $\mathrm{K}$ phosphite $\left(\mathrm{P}_{2} \mathrm{O}_{5}+\mathrm{K}_{2} \mathrm{O}\right)$ & Fertilizer (NC) & 250 & Kaliphos & Agriphos & $30+20 \mathrm{DC}$ & I and III \\
\hline
\end{tabular}

${ }^{\mathrm{x}} \mathrm{MBC}=$ methyl benzimidazole carbammates; DMI = demethylation inhibitor; QoI = quinone outside inhibitors. FRAC code number is reported in parentheses; $\mathrm{NC}=$ not classified (http://www.frac.info/frac/publication/anhang/FRAC-Code-List2011-final.pdf).

y Percentage of active ingredient. $\mathrm{WP}=$ wettable powder, $\mathrm{WG}=$ water-dispersible granule, $\mathrm{EC}=$ emulsifiable concentrate, $\mathrm{DC}=$ dispersible concentrate, $\mathrm{SC}$ $=$ suspension concentrate, $\mathrm{EW}=$ emulsion oil in water, and $\mathrm{SL}=$ soluble concentrate.

${ }^{z}$ Combinations of experiments I through VII or "All”. All fungicides were preliminarily tested in growth chamber assays on red clover. 
whether there is significant trial-treatment interaction. In the posthoc analyses, the corresponding mean values of DI were subsequently separated by Newman-Keuls $(\mathrm{NK})$ test $(P=0.01)$. Untransformed arithmetic means of DI are presented in the tables.

Because ordinal scales were adopted for MDR calculation, different nonparametric approaches were used for SS data. Kendall's coefficient of concordance $(W)$ was calculated to assess whether the rankings of the SS data are similar within each trial. In experiment I, where $W>0.9$, the SS values were at first analyzed by using Friedman's nonparametric rank test, whereas, in the remaining experiments $(W<0.75)$, the Kruskal-Wallis nonparametric one-way test was applied for individual trials, calculating $\chi^{2}$ and $P$ value associated to both tests. Following Friedman and Kruskal Wallis tests, nonparametric analyses of SS scores in all possible pairwise comparisons were performed with the Wilcoxon signed-rank and Mann-Whitney (MW) tests at $P<0.05$, respectively.

\section{Results}

Fungicide efficacy in controlling $C$. morganii and $C$. pauciramosa infections in the nursery. In all nursery experiments where $C$. morganii and $C$. pauciramosa were sprayed on young bottlebrush cuttings and feijoa plants, there was always a significant effect of fungicides on Calonectria infections $(P<0.001)$. A significant treatment-trial effect was observed for all experiments with the exception of experiment I $(P=0.15)$, which was combined. Kendall's coefficient of concordance was 0.91 for SS data in presence of $C$. morganii infections, thus indicating very high concordance between two trials (Table 2). Therefore, the two trials were combined.

All fungicides were effective in controlling Calonectria leaf symptoms according to $\mathrm{NK}$ at $P=0.01$ and nonparametric tests at $P<0.05$ (Tables 3 and 4). In experiment I, tebuconazole and thiophanate-methyl were the most effective treatments in controlling DI and MDR of C. morganiii leaf spot, while cyproconazole, propamocarb + fosetyl-Al, and K phosphite (fungicides tested only for this pathogen) provided the lowest reductions of DI and MDR compared with the control. A good efficacy in controlling C. morganii infections was also observed for fosetyl-Al, prochloraz + cyproconazole, and $\mathrm{Cu}$ hydroxide, followed by strobilurins and prochloraz (Table 3 ). In experiment II, all fungicides significantly reduced DI and MDR of leaf infections caused by $C$. pauciramosa compared with the controls. In the second trial, DI for tebuconazole was significantly lower than azoxystrobin, thiophanatemethyl, and prochloraz and MDR significantly lower than azoxystrobin (Table 4).

In experiment III, conducted on feijoa seedlings, all fungicides significantly $(P=0.01)$ reduced crown and root rot caused by $C$. pauciramosa compared with the controls (Table 5). K phosphite, fosetyl-Al, and prochloraz + cyproconazole, followed by thiophanate-methyl, $\mathrm{Cu}$ hydroxide, trifloxystrobin, cyproconazole, and azoxystrobin, provided a good control of crown and root rot. Otherwise, propamocarb + fosetyl-Al was the least effective treatment in controlling crown and root infections while prochloraz provided variable efficacy against disease in two single trials (Table 5).

Effects of fungicides against other Calonectria spp. in growth chamber experiments. In the four experiments conducted on $\mathrm{Cal}$ listemon "Masotti", a significant effect of treatments $(P \leq 0.001)$ and treatment-trial interactions $(P \leq 0.008)$ was observed for DI (Table 2). In addition, the Kendall's coefficient for SS showed low concordance $(W<0.75)$ for repeated trials within each experiment (Table 2). Therefore, individual trials are presented.

When fungicide effects were tested against $C$. polizzii in experiment IV, the DI and MDR values in the control plants ranged from 35.2 to $100 \%$ and 1.3 to 4.2 , respectively. Fosetyl-Al, followed by prochloraz + cyproconazole, consistently reduced DI and MDR of Calonectria infections the most compared with the controls, while thiophanate-methyl was ineffective in the first trial and the least effective in the second trial. In the first trial, trifloxystrobin was also ineffective in reducing DI and MDR of Calonectria infections,

Table 3. Effects of fungicides on disease incidence (DI) and mean disease rating (MDR) of leaf spot caused by Calonectria morganii on bottlebrush under nursery conditions

\begin{tabular}{lcc}
\hline Treatment & DI $(\%)^{\mathbf{x}}$ & $\mathbf{M D R}^{\mathbf{x}, \mathbf{y}}$ \\
\hline Thiophanate-methyl & $2.2 \mathrm{a}$ & $1.0 \mathrm{a}$ \\
Tebuconazole & $4.6 \mathrm{a}$ & $1.0 \mathrm{a}$ \\
Cu hydroxide & $10.8 \mathrm{abc}$ & $1.1 \mathrm{bc}$ \\
Fosetyl-Al & $10.0 \mathrm{ab}$ & $1.1 \mathrm{c}$ \\
Prochloraz + cyproconazole & $10.7 \mathrm{abc}$ & $1.1 \mathrm{~cd}$ \\
Trifloxystrobin & $20.4 \mathrm{bc}$ & $1.3 \mathrm{e}$ \\
Azoxystrobin & $20.5 \mathrm{bc}$ & $1.3 \mathrm{e}$ \\
Prochloraz & $28.0 \mathrm{c}$ & $1.3 \mathrm{de}$ \\
Propamocarb + fosetyl-Al & $60.4 \mathrm{~d}$ & $2.0 \mathrm{f}$ \\
K phosphite $\left(\mathrm{P}_{2} \mathrm{O}_{5}+\mathrm{K}_{2} \mathrm{O}\right)$ & $60.3 \mathrm{~d}$ & $2.0 \mathrm{f}$ \\
Cyproconazole & $63.6 \mathrm{~d}$ & $2.2 \mathrm{f}$ \\
Control & $93.3 \mathrm{e}$ & $3.8 \mathrm{~g}$ \\
\hline
\end{tabular}

x Pooled results of two trials. Data are the mean of three replicates of 210 young bottlebrush plants. Values followed by the same letters within a column are not significantly different according to the Newman-Keuls test $(P=0.01)$ for DI. Arcsine square root transformation was applied on percentage prior to data analysis.

y Differences among MDR (1-to-5 scale) data for each treatment were analyzed with Friedman two-way analysis of variance by mean rank scores $(P<0.001)$ followed by all pairwise multiple comparison with Wilcoxon signed-rank test $(P \leq 0.05)$.

${ }^{\mathrm{z}}$ Control $=$ untreated, inoculated seedlings.

Table 2. Effects of treatments and treatment-trial interactions on disease incidence (\%) and severity (mean disease rating) of leaf spot and crown and root rot caused by Calonectria spp. on inoculated bottlebrush and feijoa plants

\begin{tabular}{|c|c|c|c|c|c|c|}
\hline \multirow[b]{2}{*}{ Experiment } & \multirow[b]{2}{*}{ Model effect } & \multicolumn{3}{|c|}{ Disease incidence $^{\mathrm{y}}$} & \multicolumn{2}{|c|}{ Disease severity ${ }^{z}$} \\
\hline & & df & $F$ & $P$ value & $\chi^{2}$ & $W$ \\
\hline 1 & Treatment & 11 & 65.31 & $<0.001$ & $>2,500$ & 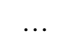 \\
\hline 1 & Treatment-trial & 11 & $1.53 \mathrm{~ns}$ & 0.15 & 59.74 & 0.91 \\
\hline 2 & Treatment & 8 & 30.19 & $<0.001$ & $>300$ & 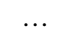 \\
\hline 2 & Treatment-trial & 8 & 2.98 & 0.011 & 27.64 & 0.58 \\
\hline 3 & Treatment & 10 & 63.08 & $<0.001$ & $>100$ & \\
\hline 3 & Treatment-trial & 10 & 4.19 & $<0.001$ & 44.14 & 0.74 \\
\hline 4 & Treatment & 8 & 48.15 & $<0.001$ & $>700$ & $\ldots$ \\
\hline 4 & Treatment-trial & 8 & 3.18 & 0.008 & 28.02 & 0.58 \\
\hline 5 & Treatment & 8 & 59.69 & $<0.001$ & $>150$ & $\ldots$ \\
\hline 5 & Treatment-trial & 8 & 19.71 & $<0.001$ & 30.80 & 0.64 \\
\hline 6 & Treatment & 8 & 147.70 & $<0.001$ & $>1,000$ & $\ldots$ \\
\hline 6 & Treatment-trial & 8 & 3.19 & 0.008 & 22.17 & 0.46 \\
\hline 7 & Treatment & 8 & 24.66 & $<0.001$ & $>300$ & \\
\hline 7 & Treatment-trial & 8 & 4.52 & $<0.001$ & 25.07 & 0.52 \\
\hline
\end{tabular}

${ }^{\text {y }} F$ test of fixed effects, $\mathrm{df}=$ degrees of freedom, and $P$ value associated to $F$; ns $=$ not significant data.

${ }^{\mathrm{z}}$ The $\chi^{2}$ values for Kruskal-Wallis one-way analysis of variance test (treatment) and Friedman two-way analysis of variance (treatment-trial), respectively; $W=$ Kendall's coefficient of concordance between repeated trials in single experiment. 
while azoxystrobin and $\mathrm{Cu}$ hydroxide were not able to significantly reduce DI values when compared with the control. Prochloraz and tebuconazole always showed a good activity in reducing DI and MDR of leaf spot caused by $C$. polizzii (Table 6). In experiment V, the MDR values on bottlebrush plants ranged from 2.4 to 3.2 while the DI was similar in two single trials, and all fungicides significantly reduced both DI and MDR of $C$. pseudomexicana leaf spot compared with the control (Table 7). However, few differences were observed among treatments in the first trial, where trifloxystrobin, followed by prochloraz, were the least effective treatments in reducing MDR of leaf spot caused by $C$. pseudomexicana (Table 7).

In experiment VI, DI and SS values of C. tunisiana on untreated bottlebrush seedlings were high, ranging from 92.9 to $100 \%$ and 2.9 to 4.0 , respectively. All fungicides significantly reduced the DI

Table 4. Effects of fungicides on disease incidence (DI) and mean disease rating (MDR) of leaf spot caused by Calonectria pauciramosa on bottlebrush under nursery conditions ${ }^{\mathrm{w}}$

\begin{tabular}{|c|c|c|c|c|}
\hline \multirow[b]{2}{*}{ Treatment } & \multicolumn{2}{|c|}{ First trial } & \multicolumn{2}{|c|}{ Second trial } \\
\hline & DI $(\%)^{x}$ & MDR $^{x, y}$ & DI $(\%)^{x}$ & MDR $^{\mathbf{x}, \mathbf{y}}$ \\
\hline Fosetyl-Al & $5.2 \mathrm{a}$ & $1.1 \mathrm{a}$ & $1.4 \mathrm{ab}$ & $1.0 \mathrm{ab}$ \\
\hline Trifloxystrobin & $4.8 \mathrm{a}$ & $1.1 \mathrm{a}$ & $1.9 \mathrm{ab}$ & $1.0 \mathrm{ab}$ \\
\hline Prochloraz & $3.8 \mathrm{a}$ & $1.1 \mathrm{a}$ & $7.6 \mathrm{~b}$ & $1.1 \mathrm{ab}$ \\
\hline $\mathrm{Cu}$ hydroxide & $4.8 \mathrm{a}$ & $1.1 \mathrm{a}$ & $1.9 \mathrm{ab}$ & $1.0 \mathrm{ab}$ \\
\hline Tebuconazole & $10.5 \mathrm{a}$ & $1.1 \mathrm{a}$ & $0.0 \mathrm{a}$ & $1.0 \mathrm{a}$ \\
\hline Prochloraz + cyproconazole & $9.1 \mathrm{a}$ & $1.2 \mathrm{a}$ & $1.9 \mathrm{ab}$ & $1.0 \mathrm{ab}$ \\
\hline Thiophanate-methyl & $13.8 \mathrm{a}$ & $1.1 \mathrm{a}$ & $9.0 \mathrm{~b}$ & $1.1 \mathrm{ab}$ \\
\hline Azoxystrobin & $11.9 \mathrm{a}$ & $1.1 \mathrm{a}$ & $11.4 \mathrm{~b}$ & $1.1 \mathrm{~b}$ \\
\hline Control $^{\mathrm{z}}$ & $56.2 \mathrm{~b}$ & $1.8 \mathrm{~b}$ & $38.6 \mathrm{c}$ & $1.7 \mathrm{c}$ \\
\hline
\end{tabular}

${ }^{w}$ The $\chi^{2}$ and $P$ values indicate the significance of the Kruskal-Wallis test. First trial, $\chi^{2}=394.1$ and $P<0.0001 ;$ second trial, $\chi^{2}=325.2$ and $P<0.0001$.

${ }^{x}$ Data are the mean of three replicates of 70 young bottlebrush plants. Values followed by the same letters within a column are not significantly different according to the Newman-Keuls test $(P=0.01)$ for DI. Arcsine square root transformation was applied on percentage prior to data analysis.

${ }^{y}$ Differences among MDR (1-to-5 scale) data for each treatment were analyzed with Kruskal-Wallis one-way analysis of variance by mean rank scores followed by all pairwise multiple comparison with Mann-Whitney test $(P \leq 0.05)$.

${ }^{\mathrm{z}}$ Control $=$ untreated, inoculated seedlings.

Table 5. Effects of fungicides on disease incidence (DI) and mean disease rating (MDR) of crown and root rot caused by Calonectria pauciramosa on feijoa under nursery conditions ${ }^{\mathrm{w}}$

\begin{tabular}{|c|c|c|c|c|}
\hline \multirow[b]{2}{*}{ Treatment } & \multicolumn{2}{|c|}{ First trial } & \multicolumn{2}{|c|}{ Second trial } \\
\hline & DI $(\%)^{x}$ & MDR $^{\mathbf{x}, \mathbf{y}}$ & DI $(\%)^{x}$ & MDR $^{\mathbf{x}, y}$ \\
\hline $\mathrm{K}$ phosphite $\left(\mathrm{P}_{2} \mathrm{O}_{5}+\mathrm{K}_{2} \mathrm{O}\right)$ & $9.4 \mathrm{a}$ & $1.1 \mathrm{a}$ & $10.4 \mathrm{a}$ & $1.1 \mathrm{a}$ \\
\hline Fosetyl-Al & $12.5 \mathrm{a}$ & $1.2 \mathrm{a}$ & $8.4 \mathrm{a}$ & $1.1 \mathrm{a}$ \\
\hline Prochloraz + cyproconazole & $14.6 \mathrm{a}$ & $1.3 \mathrm{a}$ & $9.4 \mathrm{a}$ & $1.2 \mathrm{a}$ \\
\hline Thiophanate-methyl & $15.6 \mathrm{a}$ & $1.3 \mathrm{a}$ & $11.5 \mathrm{a}$ & $1.2 \mathrm{ab}$ \\
\hline $\mathrm{Cu}$ hydroxide & $16.7 \mathrm{a}$ & $1.3 \mathrm{a}$ & $14.6 \mathrm{a}$ & $1.3 \mathrm{ab}$ \\
\hline Trifloxystrobin & $17.7 \mathrm{a}$ & $1.3 \mathrm{a}$ & $13.5 \mathrm{a}$ & $1.3 \mathrm{ab}$ \\
\hline Cyproconazole & $16.6 \mathrm{a}$ & $1.3 \mathrm{a}$ & $13.5 \mathrm{a}$ & $1.3 \mathrm{ab}$ \\
\hline Azoxystrobin & $17.7 \mathrm{a}$ & $1.4 \mathrm{ab}$ & $16.6 \mathrm{a}$ & $1.3 \mathrm{ab}$ \\
\hline Prochloraz & $37.5 \mathrm{~b}$ & $1.8 \mathrm{c}$ & $16.7 \mathrm{a}$ & $1.3 \mathrm{ab}$ \\
\hline Propamocarb + fosetyl Al & $34.4 \mathrm{~b}$ & $1.6 \mathrm{bc}$ & $27.1 \mathrm{~b}$ & $1.6 \mathrm{~b}$ \\
\hline Control $^{z}$ & $77.1 \mathrm{c}$ & $2.5 \mathrm{~d}$ & $51.0 \mathrm{c}$ & $2.1 \mathrm{c}$ \\
\hline
\end{tabular}

${ }^{\text {w }}$ The $\chi^{2}$ and $P$ values indicate the significance of the Kruskal-Wallis test. First trial, $\chi^{2}=196.9$ and $P<0.0001$; second trial, $\chi^{2}=101.2$ and $P<0.0001$.

${ }^{x}$ Data are the mean of three replicates of 32 young feijoa plants. Values followed by the same letters within a column are not significantly different according to the Newman-Keuls test $(P=0.01)$ for DI. Arcsine square root transformation was applied on percentage prior to data analysis.

${ }^{y}$ Differences among MDR (1-to-5 scale) data for each treatment were analyzed with Kruskal-Wallis one-way analysis of variance by mean rank scores followed by all pairwise multiple comparison with Mann-Whitney test $(P \leq 0.05)$.

${ }^{\mathrm{z}}$ Control $=$ untreated, inoculated seedlings.

Table 6. Effects of fungicides on disease incidence (DI) and mean disease rating (MDR) of leaf spot caused by Calonectria polizzii on bottlebrush under controlled environment conditions ${ }^{\mathrm{w}}$

\begin{tabular}{|c|c|c|c|c|}
\hline \multirow[b]{2}{*}{ Treatment } & \multicolumn{2}{|c|}{ First trial } & \multicolumn{2}{|c|}{ Second trial } \\
\hline & DI $(\%)^{x}$ & $\operatorname{MDR}^{\mathbf{x}, \mathbf{y}}$ & DI $(\%)^{x}$ & $\mathbf{M D R}^{\mathrm{x}, \mathrm{y}}$ \\
\hline Fosetyl-Al & $4.8 \mathrm{a}$ & $1.1 \mathrm{a}$ & $1.0 \mathrm{a}$ & $1.0 \mathrm{a}$ \\
\hline Prochloraz + cyproconazole & $6.7 \mathrm{a}$ & $1.1 \mathrm{a}$ & $2.4 \mathrm{ab}$ & $1.0 \mathrm{a}$ \\
\hline Prochloraz & $4.3 \mathrm{a}$ & $1.1 \mathrm{a}$ & $5.7 \mathrm{bc}$ & $1.1 \mathrm{ab}$ \\
\hline Tebuconazole & $7.1 \mathrm{a}$ & $1.2 \mathrm{a}$ & $15.2 \mathrm{c}$ & $1.3 \mathrm{~b}$ \\
\hline $\mathrm{Cu}$ hydroxide & $9.5 \mathrm{ab}$ & $1.1 \mathrm{a}$ & $9.5 \mathrm{bc}$ & $1.1 \mathrm{ab}$ \\
\hline Azoxystrobin & $12.8 \mathrm{ab}$ & $1.3 \mathrm{ab}$ & $5.7 \mathrm{bc}$ & $1.1 \mathrm{ab}$ \\
\hline Trifloxystrobin & $22.4 \mathrm{ab}$ & $1.3 \mathrm{bc}$ & $7.6 \mathrm{bc}$ & $1.1 \mathrm{ab}$ \\
\hline Thiophanate-methyl & $24.8 \mathrm{ab}$ & $1.3 \mathrm{c}$ & $57.6 \mathrm{~d}$ & $2.6 \mathrm{c}$ \\
\hline Control $^{z}$ & $35.2 \mathrm{~b}$ & $1.4 \mathrm{c}$ & $100 \mathrm{e}$ & $4.2 \mathrm{~d}$ \\
\hline
\end{tabular}

${ }^{\text {w }}$ The $\chi^{2}$ and $P$ values indicate the significance of the Kruskal-Wallis test. First trial, $\chi^{2}=162.0$ and $P<0.0001$; second trial, $\chi^{2}=1,089.0$ and $P<0.0001$.

${ }^{x}$ Data are the mean of three replicates of 70 young bottlebrush plants. Values followed by the same letters within a column are not significantly different according to the Newman-Keuls test $(P=0.01)$ for DI. Arcsine square root transformation was applied on percentage prior to data analysis.

${ }^{y}$ Differences among MDR (1-to-5 scale) data for each treatment were analyzed with Kruskal-Wallis one-way analysis of variance by mean rank scores followed by all pairwise multiple comparison with Mann-Whitney test $(P \leq 0.05)$.

${ }^{\mathrm{z}}$ Control $=$ untreated, inoculated seedlings. 
and MDR values of leaf spot compared with the controls, and thiophanate-methyl and prochloraz + cyproconazole were more effective than $\mathrm{Cu}$ hydroxide in reducing both DI and MDR of leaf spot caused by this pathogen in the first trial (Table 8).

In experiment VII, a moderate infection level caused by $C$. mexicana was observed in both trials (DI ranged from $46.2 \%$ to $57.1 \%$ and SS from 1.5 to 2.0 on control bottlebrush plants). However, all fungicides were effective in reducing DI and MDR of Calonectria leaf spot except for DI of azoxystrobin and prochloraz in the first trial. In the second trial, prochloraz + cyproconazole and fosetyl-Al were more effective than thiophanate-methyl in reducing both DI and MDR of leaf spot on bottlebrush caused by C. mexicana (Table 9).

\section{Discussion}

This research adds valuable information contributing to a valid strategy for using new and already known fungicides for managing

Table 7. Effects of fungicides on disease incidence (DI) and mean disease rating (MDR) of leaf spot caused by Calonectria pseudomexicana on bottlebrush under controlled environment conditions ${ }^{\mathrm{w}}$

\begin{tabular}{|c|c|c|c|c|}
\hline \multirow[b]{2}{*}{ Treatment } & \multicolumn{2}{|c|}{ First trial } & \multicolumn{2}{|c|}{ Second trial } \\
\hline & DI $(\%)^{x}$ & $\operatorname{MDR}^{\mathbf{x}, y}$ & DI $(\%)^{x}$ & $\operatorname{MDR}^{x, y}$ \\
\hline Fosetyl-Al & $1.4 \mathrm{a}$ & $1.0 \mathrm{a}$ & $1.9 \mathrm{a}$ & $1.0 \mathrm{a}$ \\
\hline Prochloraz + cyproconazole & $3.3 \mathrm{a}$ & $1.0 \mathrm{a}$ & $1.0 \mathrm{a}$ & $1.0 \mathrm{a}$ \\
\hline Thiophanate-methyl & $3.3 \mathrm{a}$ & $1.1 \mathrm{a}$ & $1.0 \mathrm{a}$ & $1.0 \mathrm{a}$ \\
\hline $\mathrm{Cu}$ hydroxide & $4.3 \mathrm{a}$ & $1.0 \mathrm{a}$ & $3.4 \mathrm{a}$ & $1.0 \mathrm{a}$ \\
\hline Tebuconazole & $4.3 \mathrm{a}$ & $1.0 \mathrm{a}$ & $2.4 \mathrm{a}$ & $1.0 \mathrm{a}$ \\
\hline Azoxystrobin & $8.6 \mathrm{a}$ & $1.2 \mathrm{ab}$ & $4.8 \mathrm{a}$ & $1.0 \mathrm{a}$ \\
\hline Prochloraz & $20.0 \mathrm{a}$ & $1.2 \mathrm{bc}$ & $1.0 \mathrm{a}$ & $1.0 \mathrm{a}$ \\
\hline Trifloxystrobin & $21.4 \mathrm{a}$ & $1.3 \mathrm{c}$ & $3.4 \mathrm{a}$ & $1.0 \mathrm{a}$ \\
\hline Control $^{\mathrm{z}}$ & $80.4 \mathrm{~b}$ & $2.4 \mathrm{~d}$ & $77.2 \mathrm{~b}$ & $3.2 \mathrm{~b}$ \\
\hline
\end{tabular}

${ }^{\text {w }}$ The $\chi^{2}$ and $P$ values indicate the significance of the Kruskal-Wallis test. First trial, $\chi^{2}=792.4$ and $P<0.0001$; second trial, $\chi^{2}=1,102.6$ and $P<0.0001$.

${ }^{\mathrm{x}}$ Data are the mean of three replicates of 70 young bottlebrush plants. Values followed by the same letters within a column are not significantly different according to the Newman-Keuls test $(P=0.01)$ for DI. Arcsine square root transformation was applied on percentage prior to data analysis.

y Differences among MDR (1-to-5 scale) data for each treatment were analyzed with Kruskal-Wallis one-way analysis of variance by mean rank scores followed by all pairwise multiple comparison with Mann-Whitney test $(P \leq 0.05)$.

${ }^{\mathrm{z}}$ Control $=$ untreated, inoculated seedlings.

Table 8. Effects of fungicides on disease incidence (DI) and mean disease rating (MDR) of leaf spot caused by Calonectria tunisiana on bottlebrush under controlled environment conditions ${ }^{\mathrm{w}}$

\begin{tabular}{|c|c|c|c|c|}
\hline \multirow[b]{2}{*}{ Treatment } & \multicolumn{2}{|c|}{ First trial } & \multicolumn{2}{|c|}{ Second trial } \\
\hline & DI $(\%)^{x}$ & $\operatorname{MDR}^{\mathbf{x}, \mathbf{y}}$ & DI $(\%)^{x}$ & $\operatorname{MDR}^{\mathbf{x}, \mathbf{y}}$ \\
\hline Thiophanate-methyl & $0.0 \mathrm{a}$ & $1.0 \mathrm{a}$ & $5.7 \mathrm{a}$ & $1.1 \mathrm{a}$ \\
\hline Prochloraz + cyproconazole & $0.0 \mathrm{a}$ & $1.0 \mathrm{a}$ & $6.7 \mathrm{a}$ & $1.1 \mathrm{a}$ \\
\hline Trifloxystrobin & $4.3 \mathrm{ab}$ & $1.1 \mathrm{ab}$ & $3.8 \mathrm{a}$ & $1.0 \mathrm{a}$ \\
\hline Prochloraz & $3.3 \mathrm{ab}$ & $1.0 \mathrm{ab}$ & $5.7 \mathrm{a}$ & $1.1 \mathrm{a}$ \\
\hline Tebuconazole & $3.3 \mathrm{ab}$ & $1.0 \mathrm{ab}$ & $6.7 \mathrm{a}$ & $1.1 \mathrm{a}$ \\
\hline Fosetyl-Al & $3.8 \mathrm{ab}$ & $1.0 \mathrm{ab}$ & $5.7 \mathrm{a}$ & $1.1 \mathrm{a}$ \\
\hline $\mathrm{Cu}$ hydroxide & $1.4 \mathrm{ab}$ & $1.0 \mathrm{ab}$ & $11.9 \mathrm{a}$ & $1.1 \mathrm{a}$ \\
\hline Azoxystrobin & $11.9 \mathrm{~b}$ & $1.1 \mathrm{~b}$ & $6.7 \mathrm{a}$ & $1.1 \mathrm{a}$ \\
\hline Control $^{z}$ & $92.9 \mathrm{c}$ & $2.9 \mathrm{c}$ & $100 \mathrm{~b}$ & $4.0 \mathrm{~b}$ \\
\hline
\end{tabular}

${ }^{w}$ The $\chi^{2}$ and $P$ values indicate the significance of the Kruskal-Wallis test. First trial, $\chi^{2}=1,299.0 ; P<0.0001$; second trial, $\chi^{2}=1,160.5$ and $P<0.0001$.

${ }^{x}$ Data are the mean of three replicates of 70 young bottlebrush plants. Values followed by the same letters within a column are not significantly different according to the Newman-Keuls test $(P=0.01)$ for DI. Arcsine square root transformation was applied on percentage prior to data analysis.

${ }^{y}$ Differences among MDR (1-to-5 scale) data for each treatment were analyzed with Kruskal-Wallis one-way analysis of variance by mean rank scores followed by all pairwise multiple comparison with Mann-Whitney test $(P \leq 0.05)$.

${ }^{\mathrm{z}}$ Control $=$ untreated, inoculated seedlings.

Table 9. Effects of fungicides on disease incidence (DI) and mean disease rating (MDR) of leaf spot caused by Calonectria mexicana on bottlebrush under controlled environment conditions ${ }^{\mathrm{w}}$

\begin{tabular}{|c|c|c|c|c|}
\hline \multirow[b]{2}{*}{ Treatment } & \multicolumn{2}{|c|}{ First trial } & \multicolumn{2}{|c|}{ Second trial } \\
\hline & DI $(\%)^{x}$ & MDR $^{\mathbf{x}, \mathbf{y}}$ & DI $(\%)^{x}$ & MDR $^{\mathbf{x}, \mathbf{y}}$ \\
\hline Prochloraz + cyproconazole & $1.4 \mathrm{a}$ & $1.0 \mathrm{a}$ & $0.0 \mathrm{a}$ & $1.0 \mathrm{a}$ \\
\hline Fosetyl-Al & $4.3 \mathrm{a}$ & $1.0 \mathrm{a}$ & $0.0 \mathrm{a}$ & $1.0 \mathrm{a}$ \\
\hline Trifloxystrobin & $7.6 \mathrm{a}$ & $1.1 \mathrm{a}$ & $2.9 \mathrm{ab}$ & $1.0 \mathrm{ab}$ \\
\hline $\mathrm{Cu}$ hydroxide & $6.7 \mathrm{a}$ & $1.1 \mathrm{a}$ & $4.8 \mathrm{ab}$ & $1.0 \mathrm{ab}$ \\
\hline Tebuconazole & $3.3 \mathrm{a}$ & $1.0 \mathrm{a}$ & $5.7 \mathrm{ab}$ & $1.1 \mathrm{ab}$ \\
\hline Thiophanate-methyl & $1.0 \mathrm{a}$ & $1.0 \mathrm{a}$ & $13.3 \mathrm{~b}$ & $1.3 \mathrm{~b}$ \\
\hline Azoxystrobin & $19.5 \mathrm{ab}$ & $1.2 \mathrm{~b}$ & $4.8 \mathrm{ab}$ & $1.0 \mathrm{ab}$ \\
\hline Prochloraz & $22.9 \mathrm{ab}$ & $1.2 \mathrm{~b}$ & $3.8 \mathrm{ab}$ & $1.0 \mathrm{ab}$ \\
\hline Control $^{z}$ & $46.2 \mathrm{~b}$ & $1.5 \mathrm{c}$ & $57.1 \mathrm{c}$ & $2.0 \mathrm{c}$ \\
\hline
\end{tabular}

${ }^{\mathrm{w}}$ The $\chi^{2}$ and $P$ values indicate the significance of the Kruskal-Wallis test. First trial, $\chi^{2}=336.4 ; P<0.0001$; second trial, $\chi^{2}=591.7 ; P<0.0001$.

${ }^{x}$ Data are the mean of three replicates of 70 young bottlebrush plants. Values followed by the same letters within a column are not significantly different according to the Newman-Keuls test $(P=0.01)$ for DI. Arcsine square root transformation was applied on percentage prior to data analysis.

${ }^{y}$ Differences among MDR (1-to-5 scale) data for each treatment were analyzed with Kruskal-Wallis one-way analysis of variance by mean rank scores followed by all pairwise multiple comparison with Mann-Whitney test $(P \leq 0.05)$.

${ }^{\mathrm{z}}$ Control $=$ untreated, inoculated seedlings. 
several Calonectria diseases, especially for those caused by $C$. morganii and $C$. pauciramosa that represent the majority of disease records reported from ornamental nurseries around the world $(2,8,9,15,17,18,20,24,27,28,32,39)$. Single experiments have previously shown the potential of certain fungicides to reduce incidence and severity of infections caused by $C$. morganii and $C$. pauciramosa, well established in Italian nurseries $(30,32,39,47)$, by other more sporadically occurring pathogens, such as $C$. polizzii (22), and by those exotic in Italian nurseries (C. pseudomexicana, C. tunisiana, and C. Mexicana) recently reported in Tunisia (23).

From these results, preventive applications of tebuconazole, fosetyl-Al, $\mathrm{Cu}$ hydroxide, thiophanate-methyl, prochloraz + cyproconazole, trifloxystrobin, azoxystrobin, and prochloraz could be suggested to control leaf spots caused by both $C$. morganii and $C$. pauciramosa in nurseries, whereas use of cyproconazole, propamocarb + fosetyl $\mathrm{Al}$, and $\mathrm{K}$ phosphite is discouraged. Because they provided a significant reduction of crown and root rot caused by $C$. pauciramosa on feijoa plants, $\mathrm{K}$ phosphite, fosetyl-Al, prochloraz + cyproconazole, cyproconazole, $\mathrm{Cu}$ hydroxide, thiophanate-methyl, tryfloxystrobin, and azoxystrobin should be included in fungicide application schedules. Overall, $\mathrm{K}$ phosphite did not show good efficacy against Calonectria leaf spot, although it performed well against crown and root rot caused by $C$. pauciramosa.

Among the tested fungicides, fosetyl-Al, prochloraz + cyproconazole, and tebuconazole showed the best activity also in controlling leaf spot on bottlebrush caused by C. polizzii, C. pseudomexicana, C. tunisiana, and C. mexicana.

Although thiophanate-methyl showed good efficacy in controlling Calonectria infections, it belongs to the methyl benzimidazole carbammates (MBCs) that are considered to be at high risk for the development of resistance in target populations (14). Indeed, the observed partial failure of thiophanate-methyl in reducing leaf spot caused by $C$. polizzii is due to the high resistance level (MIC $>100$ $\mu \mathrm{g} \mathrm{ml}^{-1}$ ) to MBCs of the tested isolate. Because a high prevalence of MBC-resistant Calonectria isolates has been reported $(1,35,44)$, the use of these fungicides should be seriously questioned and the exclusive use of MBCs for Calonectria spp. management avoided.

Tebuconazole reduced leaf spot caused by either $C$. morganii or C. pauciramosa. Unfortunately, the repeated use of tebuconazole in a short period is known to cause stunting and reduction of length and shoot number or root hypertrophy on bottlebrush and milkwort (Polygala myrtifolia L.; 29,46). The present study showed that copper hydroxide application could be recommended for reducing Calonectria crown and root rot as well as leaf spot, being careful to avoid repeated treatments that can cause phytotoxicity (46; G. Polizzi, unpublished data) and $\mathrm{Cu}$ accumulation in the soil. Indeed, copper compounds should be included as alternative fungicides in anti-resistance strategies to manage Calonectria spp. in the production of many susceptible ornamental species. Because of the variable results detected for prochloraz in this study, further investigations on the efficacy of this compound are needed.

The findings in our study suggest that effective fungicides having a different site of action may be integrated in appropriate fungicide application schedules for controlling Calonectria spp. For example, mixtures or alternations among tested inorganic (copper compounds), phosphonate (fosetyl-Al), quinone outside inhibitors (strobilurins), demethylation inhibitors, and MBCs fungicides could represent a sustainable strategy for achieving good control of Calonectria infections in nurseries. These rotation or tank mix strategies will also be able to minimize the risk of fungicide resistance, phytotoxicity, and environmental damage due to accumulation of heavy metals in the soil.

In addition, a fungicide-based management program against crown and root rot by $C$. pauciramosa could be supplemented with $\mathrm{K}$ phosphite fertilization, which provided very good results in the present study. Many authors have reported on the efficacy of $\mathrm{K}$ phosphite against fungal diseases on various crops $(3,4,40,41,48)$. However, the efficacy of $\mathrm{K}$ phosphite against Calonectria infections was not reported until the present study. Although its mode of action against Calonectria spp. was not studied, the plant re- sponses observed in this study are likely to be attributable to the direct effect of $\mathrm{K}$ phosphite against Calonectria spp., as was reported for other fungal plant pathogens $(10,42)$. This is supported by the fact that $\mathrm{K}$ phosphite has shown good activity against $C$. morganii and $C$. pauciramosa on red clover seedlings in a very short period and reduced mycelial growth of these fungi in vitro on PDA amended with $\mathrm{K}$ phosphite (data not shown).

Overall, management of Calonectria diseases in the nursery cannot rely on a single control measure and the steps to developing an integrated program for efficient management of these diseases is complex. Because only preventative measures were found effective for Calonectria disease control (9), chemical control would always be adopted in association with good nursery practices, including reduction of primary inoculum, removal of infected plants, and utilization of uncontaminated potting medium. Moreover, the use of other sustainable strategies as well, such as soil solarization (34) or biological control agents (45), could improve disease control.

\section{Acknowledgments}

This research was supported by MIUR (project number PON01_01611), and PRA, University of Catania. We thank V. Guarnaccia, P. T. Formica, and A. Cinquerrui for technical assistance.

\section{Literature Cited}

1. Alfenas, A. C., Demuner, N. L., and Silva, A. R. 1988. Benomyl resistant strain of Cylindrocladium scoparium causal agent of cutting rot of Eucalyptus grandis in Brazil. ISPP. Chem. Contr. Newsl. 10:23-25.

2. Alfieri, S. A., Jr., Langdon, K. R., Wehlburg, C., and Kimbrough J. W. 1984. Index of Plant Diseases in Florida (Revised). Fla. Dept. Agric. Consumer Serv. Div. Plant Ind. Bull. 11:1-389.

3. Amiri, A., and Bompeix, G. 2011. Control of Penicillium expansum with potassium phosphite and heat treatment. Crop Prot. 30:222-227.

4. Araujo, L., Valdebenito-Sanhueza, R. M., and Stadnik, M. J. 2010. Evaluation of potassium phosphite formulations against Colletotrichum gloeosporioides in vitro and for post-infection control of Glomerella leaf spot in apple. Trop. Plant Pathol. 35:54-59.

5. Backhaus, G. F. 1994. Cylindrocladium scoparium causing wilt disease in Rhododendron and Azalea. Acta Hortic. 364:163-165.

6. Barnard, E. L. 1984. Occurrence, impact, and fungicide control of girdling stem cankers caused by Cylindrocladium scoparium on Eucalyptus seedlings in a south Florida nursery. Plant Dis. 68:471-473.

7. Bertus, A. L. 1976. Cylindrocladium scoparium Morgan on Australian native plants in cultivation. Phytopathol. Z. 85:15-25.

8. Chen, S. F., Lombard, L., Roux, J., Xie, Y. J., Wingfield, M. J., and Zhou, X. D. 2011. Novel species of Calonectria associated with Eucalyptus leaf blight in Southeast China. Persoonia 26:1-12.

9. Crous, P. W. 2002. Taxonomy and Pathology of Cylindrocladium (Calonectria) and Allied Genera. American Phytopathological Society, St. Paul, MN.

10. Deliopoulos, T., Kettlewell, P. S., and Hare, M. C. 2010. Fungal disease suppression by inorganic salts: a review. Crop Prot. 29:1059-1075.

11. De Prest, G. 1988. The use of prochloraz to control Cylindrocladium scoparium Morgan during the rooting of azalea (Rhododendron simsii Planch). Meded. Fac. Landbouwwet. Rijksuniv. Gent. 53:123-128.

12. De Prest, G., and Poppe, J. 1988. Efficacy of fungicides against Cylindrocladium scoparium and their influence on azalea cuttings. Meded. Fac. Landbouwwet. Rijksuniv. Gent. 53:643-650.

13. Ferreira, E. M., Alfenas, A. C., Maffia, L. A., and Mafia, R. G. 2006. Efficiency of systemic fungicides for control of Cylindrocladium candelabrum in eucalypt. Fitopatol. Bras. 31:468-475. (In Portuguese)

14. Fungicide Resistance Action Committee. FRAC Code List: Fungicides Sorted by Mode of Action (including FRAC Code numbering). http://www.frac.info

15. Henricot, B., and Beales, P. 2003. First record of Cylindrocladium pauciramosum on myrtle (Myrtus communis) in Portugal. Plant Pathol. 52:420.

16. Henricot, B., Gorton, C., Denton, G., and Denton, J. 2008. Studies on the control of Cylindrocladium buxicola using fungicides and host resistance. Plant Dis. 92:1273-1279.

17. Koike, S. T., and Crous, P. W. 2001. First report of root and crown rot of myrtle in California caused by Cylindrocladium pauciramosum. Plant Dis. $85: 488$.

18. Koike, S. T., Henderson, D. M., Crous, P. W., Schoch, C. L., and Tjosvold, S. A. 1999. A new root and crown rot disease of heath in California caused by Cylindrocladium pauciramosum. Plant Dis. 83:589.

19. Kucharek, T. A., and Atkins, J. 1993. Occurrence and control of Cylindrocladium black rot in peanuts in Florida. Soil Crop. Sci. Soc. Fla. Proc. 52:17-20.

20. Lane, C. R., Beales, P. A., Henricot, B., and Holden, A. 2006. First record of Cylindrocladium pauciramosum on Ceanothus in the UK. Plant Pathol. 55:582. 
21. Lombard, L., Crous, P. W., Wingfield, B. D., and Wingfield, M. J. 2010. Species concepts in Calonectria (Cylindrocladium). Stud. Mycol. 66:1-14.

22. Lombard, L., Crous, P. W., Wingfield, B. D., and Wingfield, M. J. 2010. Multigene phylogeny and mating tests reveal three cryptic species related to Calonectria pauciramosa. Stud. Mycol. 66:15-30.

23. Lombard, L., Polizzi, G., Guarnaccia, V., Vitale, A., and Crous, P. W. 2011. Calonectria spp. causing leaf spot, crown and root rot of ornamental plants in Tunisia. Persoonia 27:73-79.

24. Lombard, L., Zhou, X. D., Crous, P. W., Wingfield, B. D., and Wingfield, M. J. 2010. Calonectria species associated with cutting rot of Eucalyptus. Persoonia 24:1-11.

25. Nan, Z. B., Long, P. G., and Skipp, R. A. 1992. Use of prochloraz and benomyl drenches to assess the effects of fungal root pathogens on growth of red clover under field conditions. Australas. Plant Pathol. 21:98-103.

26. Niebisch, R. M., and Kelling, K. 1986. Results of chemical control of fungal diseases in ornamental plant production. Gartenbau 33:215-218.

27. Pérez-Sierra, A., Álvarez, L. A., Henricot, B., Garcìa-Jimènez, J., and Armengol, J. 2006. Cylindrocladium pauciramosum causes root and collar rot of Polygala myrtifolia in Spain. Plant Pathol. 55:298.

28. Pérez-Sierra, A., Álvarez, L. A., Leòn, M., Abad-Campos, P., Henricot, B., Armengol, J., and Garcìa-Jimènez, J. 2007. First report of leaf spot, blight, and stem lesions caused by Cylindrocladium pauciramosum on Callistemon in Spain. Plant Dis. 91:1057.

29. Polizzi, G. 2000. Prime esperienze di lotta chimica nei confronti del marciume del colletto e delle radici di Polygala myrtifolia causato da Cylindrocladium pauciramosum. Inf. Fitopatol. 11:39-47. (In Italian)

30. Polizzi, G., and Azzaro, A. 1996. A new leaf spot disease of myrtle by Cylindrocladium scoparium and its control in nursery. Petria 6:117-123.

31. Polizzi, G., and Catara, V. 2001. First report of leaf spot caused by $\mathrm{Cyl}$ indrocladium pauciramosum on Acacia retinodes, Arbutus unedo, Feijoa sellowiana, and Dodonaea viscosa in southern Italy. Plant Dis. 85:803.

32. Polizzi, G., and Crous, P. W. 1999. Root and collar rot of milkwort caused by Cylindrocladium pauciramosum, a new record for Europe. Eur. J. Plant Pathol. 105:413-415.

33. Polizzi, G., Grasso, F. M., Vitale, A., and Aiello, D. 2007. First occurrence of Calonectria leaf spot on Mexican blue palm in Italy. Plant Dis. 91:1052.

34. Polizzi, G., La Rosa, R., Arcidiacono, C., and D'Emilio, A. 2003. Effects of innovative films in soil solarization for the control of soilborne pathogens. Acta Hortic. 614:805-811.

35. Polizzi, G., and Vitale, A. 2001. First report of the prevalence of benzimidazole-resistant isolates in a population of Cylindrocladium pauciramosum in Italy. Plant Dis. 85:1210.
36. Polizzi, G., and Vitale, A. 2002. Biocontrol of Cylindrocladium root and collar rot of myrtle-leaf milkwort by Trichoderma harzianum strain T-22. Biol. Cult. Tests Rep. 17:O14.

37. Polizzi, G., Vitale, A., Aiello, D., Dimartino, M. A., and Parlavecchio, G. 2007. First report of damping-off and leaf spot caused by Cylindrocladium scoparium on different accessions of bottlebrush cuttings in Italy. Plant Dis. 91:769.

38. Polizzi, G., Vitale, A., Aiello, D., and Parlavecchio, G. 2006. First record of crown and root rot caused by Cylindrocladium pauciramosum on California lilac in Italy. Plant Dis. 90:1459.

39. Polizzi, G., Vitale, A., Castello, I., Groenewald, J. Z., Crous, P. W. 2006. Cylindrocladium leaf spot, blight, and crown rot, new diseases of mastic tree seedlings caused by Cylindrocladium scoparium. Plant Dis. 90:1110.

40. Rebollar-Alviter, A., Wilson, L. L., Madden, L. V., and Ellis, M. A. 2010. A comparative evaluation of post-infection efficacy of mefenoxam and potassium phosphite with protectant efficacy of azoxystrobin and potassium phosphite for controlling leather rot of strawberry caused by Phytophthora cactorum. Crop Prot. 29:349-353.

41. Silva, O. C., Santos, H. A. A., Pria, M. D., and May-de Mio, L. L. 2011. Potassium phosphite for control of downy mildew of soybean. Crop Prot. 30:598-604.

42. Thao, H. T. B., and Yamakawa, T. 2009. Phosphite (phosphorous acid) fungicide, fertilizer or bio-stimulator? Soil Sci. Plant Nutr. 55:228-234.

43. Vitale, A., Aiello, D., Castello, I., Parlavecchio, G., and Polizzi, G. 2008 First report of crown rot and root rot caused by Cylindrocladium pauciramosum on feijoa (Feijoa sellowiana) in Italy. Plant Dis. 92:1590.

44. Vitale, A., Aiello, D., Castello, I., and Polizzi, G. 2009. First report of benzimidazole-resistant isolates of Cylindrocladium scoparium in Europe. Plant Dis. 93:110.

45. Vitale, A., Cirvilleri, G., Castello, I., Aiello, D., and Polizzi, G. 2011 Evaluation of Trichoderma harzianum strain T22 as biological control agent of Calonectria pauciramosa. Biocontrol. Online publication. doi:10.1007/ s10526-011-9423-1

46. Vitale, A., Gimmillaro, M., and Polizzi, G. 2003. Prove triennali di lotta con mezzi chimici e biologici per il contenimento di Cylindrocladium pauciramosum in vivaio. Italus Hortus 10(S4):315-320. (In Italian)

47. Vitale, A., and Polizzi, G. 2008. First record of leaf spots and stem lesions on Pistacia lentiscus caused by Cylindrocladium pauciramosum and C. scoparium in Italy. Plant Pathol. 57:384.

48. Wordell Filho, J. A., and Stadnik, M. J. 2010. Effect of potassium phosphite and manganese phosphite on downy mildew of the onion. Agropecuaria $\mathrm{Ca}$ tarinense 23:84-87. (In Portuguese) 